\title{
The Value of Education and Work in the Representatives of Gymnasts' Opinion
}

DOI: $10.2478 / v 10131-0015-8$

Authors' Contribution:

A - Study Design

B - Data Collection

C - Statistical Analysis

D - Data Interpretation

E - Manuscript Preparation

$F$ - Literature Search

$G$ - Funds Collection

\author{
Anna Perzyńska-Biskup $1(A, B, C, D, E, F, G)$, \\ Stanisław Sawczyn $2(A, B, C, D, E, F, G)$ \\ ${ }^{1}$ University School of Physical Education in Cracow, Poland \\ 2 Jedrzej Sniadecki Academy of Physical Education and Sport in Gdansk, \\ Poland
}

Key words: sport, woman, gymnastics, education, work, sociology.

\section{Abstract}

Background: Sports professional activity has been an unusually absorbing domain of human life. This is particularly noticeable in so-called sports of early specialization, including gymnastics. The specialization in gymnastics occurs at the moment of girls' acquisition of knowledge and preparation for future professional careers. Therefore, the authors decided to look further into the process of combining school and sports duties and to reveal possible conflicts.

Material/Methods: Research material was a group of 482 athletes who are professionally involved in three gymnastics disciplines: artistic gymnastics, rhythmic gymnastics and acrobatic gymnastics in Polish clubs.

Results: An analysis of the results revealed that considerable importance is attached to the value of knowledge in both studied populations. Furthermore, the obtained empirical data contradict the popular belief that taking up professional sports activity puts obstacles in the way of combining school and sports duties and, in consequence, interferes with receiving an education.

Conclusions: Both studied populations are characterized by high recognition for the values of knowledge, education and work.

Word count: 1949

Tables: $3 \quad$ Received: October 2010

Figures: - $\quad$ Accepted: November 2010

References: $16 \quad$ Published: December 2010

Address for correspondence:

Dr Anna Perzyńska-Biskup

University School of Physical Educationin Cracow, Department of Theory and Methodics of Gymnastics

Al. Jana Pawła II 78, 31-571 Kraków

Phone: +48602-328-206, e-mail: aniagim@poczta.fm 


\section{Introduction}

Physical culture covers a number of various physical activities, starting from fundamental forms, such as physical education, through recreational forms of physical activity, to highlyspecialized professional sports [1]. Professional sports activity has recently become an unusually absorbing domain of life and athletes who embark on these careers are burdened with a number of duties [2]. They involve performance of many social roles at the same time, such as the role of a sportsman, child or student $[3,4,5,6]$.

This is particularly noticeable in so-called sports of early specialization, including gymnastics. The specialization is accompanied by an athlete's acquisition of knowledge and preparation for future professional careers. Therefore, the authors decided to look further into the process of combining school and sports duties and to reveal possible conflict situations generated in gymnasts' environments $[7,8]$.

Revealing the studied subjects' attitudes to work and a vision of what the future will look like after retiring from sports also seem to be very precious information. With professional sport of today, the concept of amateur sport is fading away while any activity taken by sportsmen gets them closer to professional work $[9,10]$. Since representatives of gymnastics disciplines attribute the properties of work to sports activities [11], the authors decided to find how work is perceived in the environment of gymnasts, which aspects are highly valued and if sports activity is identified with professional activity.

\section{Material and method}

Research material involved a group of 482 athletes who are professionally engaged in three gymnastics disciplines: artistic gymnastics, rhythmic gymnastics and acrobatic gymnastics in Polish clubs. Empirical studies covered 272 female gymnasts who are currently actively involved in sport (current, A generation) and 210 females who have already finished their professional careers (former, B generation).

The studied female gymnasts represented three sports levels: lower (2nd sports class), medium (1st sports class) and the highest level which included gymnasts of the champion class at the national and international level. The studies also considered three categories of championship experience and two age categories in each generation.

The basic technique for collecting empirical material was a social survey, questionnaire and observation. The material was then statistically analysed using $\mathrm{V}$ Cramer coefficient which confirms statistically significant relationships. Among the replies to the asked questions, individual percentage shares do not give a total of $100 \%$, since respondents were allowed to give several examples.

\section{Results and discussion}

Since practicing gymnastics converges with the period of beginning and continuation of school education and then preparation for future professional work, the author decided to check the opinions of the studied persons in terms of the importance of education which functions in the gymnasts' awareness. A fundamental goal was to determine if education, as a value, is accompanied, or was accompanied in the past, by high recognition in the awareness area. In order to achieve this, the respondents were asked an open question: Would it be still worth continuing education if the diploma of higher education was not necessary to get a good position at work? Why? This question gave an opportunity to determine if education appears to the respondents to be an autotelic value (answers which prove that it is worth to be educated above all) or an instrumental value (answers of 'it doesn't make sense' or 'I don't know' or 'it is worth doing since it makes lives easier' or 'in order to widen knowledge'). Collective results for the answers to the above mentioned questions, according to generation-based differentiation, are given in Table 1. 
Although an analysis of the statements reveals a dominance of the standpoint that it is worthwhile, above all, to keep on learning, a quarter of current gymnasts did not reveal interest in this problem. Contrary views were formulated sporadically and represented more often by the athletes of $B$ generation.

A characteristic tendency among older former sportswomen who showed highest sports level and longest professional experience is an autotelic approach to education, connected with expressional understanding of its value (satisfaction, wider horizons) ( $V$ Cramer coefficient: for generation variable 0.400 at $p=0.000$, for the age 0.394 at $p=0.000$, for sports level 0.161 at $p=0.002$, for competition experience 0.138 at $p=0.010$ ). In population $A$, a recognition of instrumental values was observed: the respondents found education to be the means to achieve other values rather than the value itself (an opportunity to aquire knowledge, entering into personal contacts or fixing up personal things).

Tab. 1. Value of education in studied gymnasts' opinion, according to generations (\%)

\begin{tabular}{|l|c|c|c|}
\hline \multicolumn{1}{|c|}{ Values of education } & \multicolumn{2}{|c|}{$\begin{array}{c}\text { Categories of } \\
\text { competitors }\end{array}$} & \multirow{2}{*}{ Total } \\
\cline { 2 - 3 } & Current & Former & \\
\hline It is worth being educated in order to acquire knowledge & 33.09 & 27.62 & 30.71 \\
It is worth for your own satisfaction, self-esteem & 25.00 & 37.14 & 30.29 \\
It is worth for a better understanding of the world, extending & & & \\
horizons & 5.88 & 38.10 & 19.92 \\
It is worth although the diploma does not present any value, but it & & & \\
helps to fix up things & 18.01 & 2.86 & 11.41 \\
It is worth due to an opportunity to enter into new contacts & 2.21 & 15.71 & 8.09 \\
It doesn't make sense to be educated & 2.57 & 15.24 & 8.09 \\
I don't know & 25.37 & 10.00 & 18.67 \\
\hline
\end{tabular}

In consideration of this high recognition of the importance of education, the author decided to verify if acquisition of knowledge interfered with fulfilment of sport-related duties by the gymnasts. This issue is of growing importance in the aspect of contemporary gymnastics which requires from young girls a great amount of time and effort $[12,13]$. The response to the question: "Has sports disturbed your learning or receiving education?" can be illustrated by three types of approach, presented in Table 2.

Tab. 2. Sport and opportunities for learning, according to generations and competitive experience (\%)

\begin{tabular}{|l|c|c|c|c|c|c|c|c|}
\hline \multirow{2}{*}{ Opinion } & \multicolumn{6}{|c|}{ Categories of competitors } \\
\cline { 2 - 9 } & \multicolumn{3}{|c|}{ Competitive experience } & \multicolumn{5}{c|}{ Competitive experience } \\
\cline { 2 - 9 } & $\begin{array}{c}2-5 \\
\text { years }\end{array}$ & $\begin{array}{c}6-9 \\
\text { years }\end{array}$ & $\begin{array}{c}10 \text { and } \\
\text { more }\end{array}$ & Total & $\begin{array}{c}2-5 \\
\text { years }\end{array}$ & $\begin{array}{c}6-9 \\
\text { years }\end{array}$ & $\begin{array}{c}10 \text { and } \\
\text { more }\end{array}$ & Total \\
\hline $\begin{array}{l}\text { Yes, it interferes } \\
\text { No, it doesn't } \\
\text { interfere }\end{array}$ & 9.38 & 14.57 & 14.04 & 13.24 & - & 11.39 & 8.62 & 9.05 \\
I don't know & 68.75 & 48.34 & 43.86 & 52.21 & 100.0 & 75.95 & 77.59 & 78.57 \\
\hline
\end{tabular}

Contrary to a popular belief, the empirical data show that taking up professional sports activity puts obstacles in the way of combining school and sports duties and, in consequence, it interferes with receiving education.

As results from Table 2, over two thirds of the respondents did not notice difficulties in performing the role of a student and a sportsperson, whereas a rise in professional experience in 
both groups by c. $23 \%$ caused a decrease in the percentage of persons who expressed this opinion.

Although competition experience revealed some disproportions in the frequency of statements, these differences were not statistically significant. More differentiating variables included a generation variable, age and the sports level. ( $V$ Cramer coefficient: for generation variable 0.281; for the age 0.203; for competition experience 0.115). They informed about the lack of difficulties in learning and professional education among older competitors of B generation who represented the lowest sports level. The opposite approach, pointing to an interference of sport and learning, was typical of younger, current gymnasts of the champion class. A relatively high percentage of indecisive statements in A generation (35\%) might point to the lack of interest in the problems or difficulties in settling the above mentioned dilemma.

Therefore, it can be argued that both populations are dominated by tendencies to acquire knowledge and receive education. However, the burden of contemporary professional sport has a direct bearing on the opportunities for the acquisition of knowledge, although competitors from all gymnastic disciplines do not perceive essential obstacles to satisfy the need for learning and selfimprovement.

After initial determination that the acquisition of knowledge and education is perceived by the respondents as an essential value for receiving professional education and finding good jobs, one should go deeper into the idea of work. In order to demonstrate it, the questions were asked about highly valued aspects of work. A recognition of particular values of work present in the awareness of the studied women was supported with an analysis of the choice of opinions from a list presented to the respondents. To construe the list of particular values, guidelines from other studies were employed [14], supported with good knowledge of the studied environment.

Table 3 reveals a large convergence of both studied populations with the view that the most valued aspects of work are 'sufficient salary' and 'interesting job'. Furthermore, the group of aspects where indications in the individual generation exceeded $40 \%$ was extended with 'permanent job' (population A) and 'good team of co-workers'. Therefore, instrumental values are dominant among gymnasts. Other aspects which were indicated by more than $20 \%$ in A generation include: 'good working conditions', 'work which is safe for your health' and 'promotion opportunities,' whereas in B generation: 'permanent job' and 'recognition gained for work'. Other choices of the values of work did not exceed several percent.

Tab. 3. Aspects of work in respondents' opinion, according to generations (\%)

\begin{tabular}{|l|c|c|c|}
\hline \multirow{2}{*}{ Aspect of work } & Categories of competitors & \multirow{2}{*}{ Total } \\
\cline { 2 - 3 } & Current & Former & \\
\hline Sufficient salary & 58.46 & 66.67 & 62.03 \\
Interesting job & 42.28 & 55.24 & 47.93 \\
Good team of co-workers & 37.13 & 41.43 & 39.00 \\
Permanent job, without fears for being moved or fired & 40.07 & 27.14 & 34.44 \\
Good working conditions & 24.63 & 19.52 & 22.41 \\
Job which is safe for your health & 27.57 & 7.62 & 18.88 \\
Promotion opportunities & 21.69 & 14.76 & 18.67 \\
Recognition for work & 6.99 & 25.71 & 15.15 \\
Good working organization & 9.93 & 13.81 & 11.62 \\
Good direct managers & 4.78 & 11.90 & 7.88 \\
Employer's care for workers & 7.35 & 4.76 & 6.22 \\
Proximity of the workplace from the place of residence & 2.21 & 3.33 & 2.70 \\
\hline
\end{tabular}

A deeper analysis of these results allowed for a determination that all variables showed statistically significant relationship, whereas the biggest relationship was perceived in the case of age variable concerning 'recognition gained for work'. It was observed that professional work does not compare to a sports activity in this aspect and does not satisfy the needs for acceptance and 
approval in the group of current younger (and with shortest training experience) gymnasts ( $\mathrm{V}$ Cramer coefficient: for generation variable 0.259 at $p=0.000$, for age 0.300 at $p=0.000$, for competition experience 0.142 , at $p=0.008$ ). This might result from the fact that young female gymnasts involved in professional sport expect a social recognition for current activities, but do not think about further future or do not expect repeating the success during a professional career [15].

A particular relationship can be observed during an analysis of the factor of health-related aspects of professional work. The results of the study confirm high assessment of health-related values of different forms of activity in each life phase, with a particular recognition among younger female gymnasts who demonstrate the lowest level and shortest experience in gymnastics ( $V$ Cramer coefficient: for generation variable 0.253 , at $p=0.000$; for age 0.266 , at $p=0.000$; for sports level 0.190 , at $p=0.000$; for sports experience 0.113 , at $p=0.014$ ) [16].

Another tendency observed in gymnasts' environment is the importance of maintaining 'permanent job' which is increasing in the course of time. With the contemporary rise in the unemployment rate, fears for maintaining a good job, or frequently any job, overshadows other aspects of professional activity. This fear is typically dominant among older current female gymnasts who notice a problem of unemployment among families and the closest environment ( $\mathrm{V}$ Cramer coefficient: for generation variable 0.135 , at $p=0.003$; for age 0.172 , at $p=0.003$ ).

\section{Conclusions}

The analysis of the results of the study allows for drawing the following conclusions:

1. Both studied populations are characterized by high recognition for the values of knowledge and education.

2. The sports activity taken up by young female gymnasts does not cause the sense of conflict resulting from performing the role of both a student and a sportswomen.

3. Among the highly valued aspects of work, the female competitors of gymnastics slightly prefer instrumental to autotelic values.

\section{References}

1. Grabowski H. Teoria fizycznej edukacji [Theory of physical education]. Warszawa: WSiP; 1997 [in Polish].

2. Lenartowicz M, Dziubiński Z, Jankowski KW, Rymarczyk P. Socialization, motives and barriers of practising sport by top-level national athletes in selected sports. In: Jutting $\mathrm{DH}$, Schulze B, Muller U, editors. Local Sport in Europe. Proceedings of 4th EASS Conference, Munster, Germany; 2008; 157166.

3. Cynarski WJ, Litwiniuk A. Hierarchy of values in case of practitioners of far eastern martial arts in Poland, Int J East Sport Phys Educ 2008;6(1):263-291.

4. Krawczyk Z. Sport w zmieniającym się społeczeństwie [Sport in a changing society]. Warszawa: AWF; 2000 [in Polish].

5. Hajduk E. Wzory przebiegu życia [Patterns of life-paths]. Zielona Góra: Lubuskie Towarzystwo Naukowe;1996 [in Polish].

6. Krawczyk B. Rola społeczna a uczestnictwo w kulturze [Social role vs. participation in culture]. In: Krawczyk Z, editor. Sport w społeczeństwie współczesnym [Sport in a contemporary society]. Warszawa: PWN; 1973: 297-315 [in Polish].

7. Jankowski KW, Lenartowicz M, Rymarczyk P, Wanat S. Socialisation, motives and barriers of practising sport by top national athletes in selected sports. Physical Culture and Sport Studies and Research 2007;1(XLV):173-186.

8. Sekuła-Kwaśniewicz H. Mikrostrukturalne wyznaczniki konfliktu ról społecznych $w$ sporcie [Mictrostructural determinants of conflict of social roles in sport]. Rocznik Naukowy AWF Kraków 1994;XXVII:5-17 [in Polish].

9. Karolczak-Biernacka B. Sport. Studium psychologiczne [Sport. A psychological study]. Warszawa: AWF; 1991 [in Polish].

10. Weiss O. Social recognition in sport. In: Kosiewicz J, Obodyński K, editors. Sport in the mirror of values. Rzeszów: UR; 2003: 32-40. 
11. Perzyńska-Biskup A, Kapik-Gruca K, Lipka-Nowak D. Obciążenia psychofizyczne a samopoczucie zawodników sportu wyczynowego [Psychophysical loads vs. state of minds of professionam athletes]. In: Turowski K, editor. Wpływ zdrowego i niezdrowego stylu życia na dobrostan [Influence of healthy and unhealthy lifestyle on wellbeing]. Lublin: Wydawnictwo Neurocentrum; 2008: 169-177 [in Polish].

12. Sawczyn S. Obciążenia treningowe w gimnastyce sportowej w wieloletnim procesie przygotowań [Training loads in sports gymnastics during a many-year preparation process]. Gdańsk: AWFiS; 2008 [in Polish].

13. Sawczyn S. Podstawy kontroli obciążeń treningowych w gimnastyce sportowej [Basics of training loads control in sports gimnastics]. Gdańsk: AWF; 2000 [in Polish].

14. Sekuła-Kwaśniewicz H. Sport zawodniczy a style życia. Studium socjologiczne kobiet czynnych w sporcie [Professional sport vs. lifestyles. A sociological study of sportswomen]. Kraków: AWF; 1991 [in Polish].

15. Basiaga-Pasternak J, Mirek W. Values hierarchy of students on the Academy of Physical Education, Annales Uniwersitatis Marie Curie-Skłodowska 2005;LX(SUPPL. XVI),15 SECTIO D:56-63.

16. Cynarski WJ. Hierarchy of values in case of the ones practicing martial arts in the Podkarpacie region. Przegląd Naukowy Kultury Fizycznej 2006;9(2):245-256. 